\title{
MEMOIR
}

\section{MILTON CROMWELL ALDER}

Milton Cromwell Alder died on 23 March i961 at the age of 73, after a brief illness. He leaves a name known and honoured not only throughout the insurance and actuarial fraternity of Australia and New Zealand but also in the many other avenues of life in which he walked.

He was born on 5 May 1887 and educated at Sydney High School and at the examination on leaving school he obtained the best pass in the State of New South Wales, receiving the award for general proficiency.

He entered the service of the Citizens' Life Assurance Company (afterwards to become The Mutual Life and Citizens' Assurance Company) in the year I902 as a junior and rose in $194 \mathrm{I}$ to the position of General Manager. On his retirement from that position in 1955 he was appointed Deputy Chairman of the Board of Directors, which position he held until his death. During his term as General Manager of this Company he was an outstanding figure in life assurance circles in Australia and was on a number of occasions Chairman of the Life Offices' Association for Australasia. He became interested in actuarial work at an early age and attained his Associateship in the year 1908. He was not, however, a specialist by temperament and did not proceed further with his actuarial studies although he always retained a very active interest in actuarial affairs. He was an enthusiastic supporter of the Actuarial Society of Australia and New Zealand which, when he obtained his Associateship, was in its infancy. He served as its Secretary for a number of years and as its President in the year I921. He was a familiar figure at sessional meetings of the Society right up to his retirement and read a number of papers at its meetings, the last in the year 1953 entitled 'Notes on the Investment of Life Assurance Funds'-a subject in which he had had a wealth of experience. He was always interested in encouraging suitable young men to take up actuarial work and not a few actuaries in Sydney owe to him their introduction to the profession.

The breadth of Alder's interests extended far beyond the Company which he served so ably. He served as President of the Insurance Institute of New South Wales and of the Economic Society of Australia and New Zealand, and was for fourteen years on the Appointments Board of the University of Sydney and for twelve years a member of the Australian National Committee of the International Chamber of Commerce.

He gave of himself without stint to activities which benefited his fellow man. In recent years he had been President of the Council of Social Service of New South Wales and Chairman of its Executive Committee, Vice-Chairman of the Old Peoples' Welfare Council, Honorary Treasurer of Toc $\mathrm{H}$ and Chairman of the Financial Committee of the Australian Rheumatism Council. In 1956-57 he was President of the Rotary Club of Sydney.

He was a keen Church worker and applied his great abilities both as an officer of his local Church and as a member of numerous committees of the Diocese of Sydney.

It was aptly said of him after his passing that 'he was a good man full of faith ... of strong convictions, sound principles and great humility....He was full of faith -in God, in his fellow man, in the future of Australia....'

A. H. POLLARD 